\title{
Kegagalan Kognitif Karyawan di Masa Pandemi: Apakah Pengaturan Kerja Fleksibel dan Persepsi Kontrol Berperan?
}

\author{
Employee's Cognitive Failure during Pandemic: Do Flexible Work \\ Arrangements and Perceived Control Play a Role?
}

Dea Shahnaz Virginia ${ }^{1}$, Arum Etikariena ${ }^{2}$

1,2Fakultas Psikologi, Universitas Indonesia

\begin{abstract}
The current situation of the COVID-19 pandemic, has an impact on limiting human activities, one of which is in terms of work. Most companies decided to implement flexible work arrangements (FWA) for employees. In addition to limiting the spread of the virus, FWA has been found to play role in reducing individual's cognitive failure both at work and at home. Besides that, perceived control can also help to reduce cognitive failure experienced by employees. Respondents of this study were 225 employees from companies in Indonesia. The data were analyzed using the PROCESS macro program by Hayes. The result showed that perceived control at work acts as a mediator in the relationship between FWA and cognitive failure at work ( $\beta=-0.003, S E=0.01,95 \%$ BCa CI [-0.07. -0.01$])$. However, it was not found in the relationship between FWA and cognitive failure at home, nor was in cross-domain relationships. This study aimed to look at the role of FWA implementation on individual's perceived control at work and at home, which can reduce individual's cognitive failure, especially during pandemic situation.
\end{abstract}

Keywords: cognitive failure; COVID-19; flexible work arrangements (FWA); perceived control

Abstrak. Situasi pandemi COVID-19 yang tengah terjadi saat ini, berdampak pada pembatasan aktivitas manusia, salah satunya dalam hal pekerjaan. Sebagian besar perusahaan memutuskan menerapkan pengaturan kerja fleksibel bagi para karyawan. Selain untuk membatasi penyebaran virus, bekerja secara fleksibel berperan dalam menurunkan kegagalan kognitif individu, baik di tempat kerja maupun di rumah. Selain itu kontrol yang baik juga membantu penurunan kegagalan kognitif yang dialami karyawan. Responden penelitian merupakan karyawan perusahaan di Indonesia yang berjumlah 225 orang. Data dianalisis menggunakan program makro PROCESS oleh Hayes. Hasil penelitian menunjukkan persepsi kontrol di tempat kerja berperan sebagai mediator dalam hubungan antara pengaturan kerja fleksibel dengan kegagalan kognitif di tempat kerja $(\beta=-0,003, S E=0,01,95 \% B C a C I[-0,07 .-0,01])$. Akan tetapi, tidak ditemukan peran mediator dalam hubungan antara pengaturan kerja fleksibel dengan kegagalan kognitif di rumah, maupun dalam hubungan lintas domain. Penelitian ini bertujuan untuk melihat peran penerapan pengaturan kerja fleksibel terhadap kontrol individu atas tanggung jawab pekerjaan dan rumah tangga, yang dapat menurunkan kegagalan kognitif individu, khususnya dalam situasi pandemi.

Kata kunci: COVID-19; kegagalan kognitif; pengaturan kerja fleksibel; persepsi kontrol 
Pada awal bulan Maret tahun 2020, Presiden Joko Widodo mengumumkan secara langsung terkait kasus pertama yang terjangkit COVID-19 atau Virus Corona (Ihsanuddin, 2020). Sejak saat itu, kasus COVID-19 di Indonesia mulai merebak. Hingga per tanggal 20 September 2020, tercatat 244.676 kasus positif tersebar di seluruh Indonesia (Hakim et al., 2020). Penyebaran virus yang cepat dan luas, membuat pemerintah mengimbau masyarakat untuk membatasi kontak fisik antar satu sama lain. Salah satu langkah yang dilakukan adalah dengan menerapkan pembatasan sosial berskala besar (PSBB). Sampai dengan bulan September, di DKI Jakarta sendiri telah diberlakukan PSBB total fase pertama, PSBB fase transisi, dan PSBB total fase kedua yang ditetapkan mulai tanggal 14 September hingga 27 September 2020 (Velarosdela, 2020).

Mengacu pada Peraturan Menteri Kesehatan Nomor 9 (2020) terkait pedoman penerapan PSBB, terdapat kebijakan yang mengatur bahwa sebagian besar proses bekerja organisasi/perusahaan dilakukan di rumah/tempat tinggal, untuk menjaga produktivitas pekerja dengan tetap berupaya menekan penyebaran COVID-19. Lalu bagaimana, tanggapan karyawan terkait penerapan bekerja dari rumah atau disebut sebagai work from home (WFH)?. Berdasarkan hasil wawancara dengan dua orang karyawan perusahaan di Jakarta, ditemukan bahwa pada dua minggu pertama penerapan WFH, ada perasaan optimis karena produktivitas kerja meningkat (Fachriansyah, 2020). Akan tetapi, sejak minggu ketiga mulai muncul perasaan cemas dan bosan. Diungkapkan pula bahwa WFH lebih banyak menimbulkan stres, beban kerja bertambah, dan sulit mengatur waktu kerja. Selain itu, WFH membuat sulit untuk bertemu dengan rekan kerja, yang merupakan salah satu sarana melepas penat dari tugas kantor, bahkan hingga mengganggu siklus tidur (Fachriansyah, 2020).

Dampak negatif WFH yang dirasakan sesuai dengan hasil beberapa penelitian terdahulu. Maruyama dan Tietze (2012) menemukan bahwa individu yang menerapkan cara kerja fleksibel kehilangan interaksi dengan rekan kerjanya, baik secara profesional maupun sosial. Dijelaskan juga bahwa beban kerja selama menerapkan pengaturan kerja fleksibel atau flexible work arrangements (FWA) justru tidak berkurang, bahkan menjadi lebih banyak. Hal ini berdampak pada tingginya tingkat stres individu. Selain itu, penelitian lain mengungkapkan pekerja yang menerapkan FWA menampilkan usaha lebih keras ketika berada di jam kerjanya, dan sering kali tetap bekerja di luar jadwal kerja yang ditentukan (Kelliher \& Anderson, 2010). Temuan lain mengungkapkan bahwa penerapan FWA dapat berdampak pada kesulitan memisahkan waktu dan ruang antara urusan pekerjaan, keluarga, dan kebutuhan pribadi. Bahkan urusan pekerjaan dapat mengganggu urusan personal lain seolah tanpa batasan (Rocha \& Amador, 2018).

Meskipun demikian, tidak sedikit yang menemukan bahwa penerapan FWA dapat berdampak positif bagi karyawan. Beberapa penelitian mengemukakan bahwa FWA dapat meningkatkan kinerja (Bloom et al., 2015), produktivitas (International Workplace Group, 2019), otonomi yang lebih baik dalam mengatur porsi kewajiban terkait pekerjaan 
dan kehidupan pribadi (Thulin et al., 2019), kepuasan kerja dan komitmen terhadap organisasi/perusahaan (Chen \& Fulmer, 2018; Manoochehri \& Pinkerton, 2003), penurunan tingkat turnover dan stres (Allen et al., 2015), menurunkan tingkat burnout (Wattree, 2020), serta meningkatkan keseimbangan antara pekerjaan dan kehidupan (Allen et al., 2013). Salah satu penelitian menarik terkait FWA adalah milik Hsu et al. (2019) yang menemukan bahwa penerapan FWA, berupa fleksibilitas waktu (flexitime) dapat berperan dalam menurunkan kegagalan kognitif individu.

Berdasarkan pengakuan dua orang karyawan di Jakarta (Fachriansyah, 2020), dikatakan bahwa beban kerja mereka meningkat dengan adanya perubahan peraturan kerja yang baru. Hal ini perlu menjadi perhatian bagi para karyawan, sebab pemikiran terkait beban kerja tersebut cenderung mengalihkan seseorang dari aktivitas rutin yang biasa dilakukan sehari-hari (Elfering et al., 2013). Kekeliruan yang dilakukan ketika seseorang melakukan aktivitas yang merupakan rutinitas ini disebut dengan istilah kegagalan kognitif atau cognitive failure. Kegagalan kognitif dapat terjadi di mana saja, termasuk di tempat kerja dan di rumah. Kegagalan kognitif di tempat kerja oleh Wallace dan Chen (2005) disebut dengan istilah Workplace Cognitife Failure (WCF) dalam penelitiannya untuk mengembangkan alat ukur kegagalan kognitif di tempat kerja (Workplace Cognitive Failure Scale). Beberapa bentuk terjadinya kegagalan kognitif di tempat kerja antara lain, tidak fokus ketika sedang mengikuti rapat atau lupa tata cara menggunakan mesin fotokopi. Sedangkan kegagalan kognitif di rumah, dikenal dengan istilah Home Cognitive Failure (HCF) yang didefinisikan sebagai kehilangan atensi, memori, dan fungsi motorik ketika mengerjakan pekerjaan atau tanggung jawab rumah tangga (Hsu et al., 2019). Bentuk terjadinya kegagalan kognitif di rumah misalnya, sering lupa di mana meletakkan barang-barang yang sering digunakan (contohnya kunci atau remote control televisi), atau tanpa sengaja mematikan pendingin ruangan ketika ingin mengatur suhu.

Secara umum kegagalan kognitif dijelaskan sebagai kesalahan yang dilakukan seseorang baik terkait pikiran atau perbuatan, yang sebenarnya dapat dilakukan tanpa kesalahan dalam keadaan normal (Broadbent et al., 1982). Kegagalan kognitif ditandai dengan kehilangan atensi, memori, dan fungsi motorik (Broadbent et al., 1982; Wallace \& Chen, 2005). Terjadinya kegagalan kognitif dapat menimbulkan dampak negatif terhadap keberlangsungan aktivitas sehari-hari. Hal ini tidak bisa dianggap sepele, sebab kegagalan kognitif dapat berujung pada kecelakaan kerja dan juga stres berlebih (Broadbent et al., 1982; Elfering et al., 2013; Elfering et al., 2015; Elfering et al., 2012; Elsayed et al., 2019). Dalam masa pandemi ini, beban kerja berlebih bisa jadi sangat rentan dalam meningkatkan kegagalan kognitif. Oleh karena itu penelitian untuk menemukan faktor yang menurunkan tingkat kegagalan kognitif penting dilakukan.

Dalam penelitian Hsu et al. (2019), menggali hal yang dapat menurunkan tingkat kegagalan kognitif menggunakan teori Conservation of Resources (COR). Kegagalan 
kognitif dapat terjadi karena manusia kekurangan energi akibat beban pemrosesan informasi dan tuntutan kognitif yang berlebih. Berdasarkan teori COR (Hobfoll, 2002), sebagai upaya untuk mencegah kekurangan energi, individu akan berusaha mencari energi dengan cara lain. Chen dan Fulmer (2018) menyatakan bahwa penerapan waktu kerja fleksibel menjadi salah satu pasokan energi bagi karyawan, sebab membuat karyawan merasa dihargai oleh perusahaan. Berdasarkan temuan tersebut, maka Hsu et al. (2019) melihat penerapan waktu kerja fleksibel sebagai sumber energi yang dapat menurunkan tingkat kegagalan kognitif.

Selain itu, penerapan FWA dapat memberikan individu otonomi terkait pilihan waktu dan tempat kerja. Oleh karena itu, FWA dapat memberikan energi kepada individu untuk menyeimbangkan antara tanggung jawab pekerjaan dengan tanggung jawab di rumah (Chen \& Fulmer, 2018). Lebih lanjut lagi, Hsu et al. (2019) mengungkapkan bahwa karyawan yang menerapkan FWA memiliki tingkat kontrol yang tinggi terkait tugas-tugas pekerjaan dan rumah, sebab mereka memiliki kebebasan dalam mengatur tugas serta batas waktu pengerjaan tugas. Kontrol yang baik terkait tanggung jawab pekerjaan dan rumah terbukti efektif dalam menurunkan isu terkait keseimbangan kehidupan pekerjaan dan keluarga (Thomas \& Ganster, 1995), beban kognitif (Binnewies et al., 2009), serta ketegangan individu (Kelly \& Moen, 2007).

Dalam penelitian terkait hubungan pekerjaan dan keluarga (Lapierre \& Allen, 2012), dikatakan bahwa kontrol merupakan salah satu bentuk personal resources, yang berkontribusi dalam menurunkan konflik terkait pekerjaan dan keluarga. Sebab kontrol yang tinggi memungkinkan individu terhindar dari situasi suatu peran mengganggu keberlangsungan peran lainnya (Lapierre \& Allen, 2012). Oleh karena itu, persepsi kontrol individu atau perceived control, baik di tempat kerja maupun di rumah menjadi aspek yang tak kalah penting dalam menentukan keberhasilan penerapan FWA untuk dapat menurunkan tingkat kegagalan kognitif seseorang.

Berdasarkan penjelasan di atas, maka penelitian ini akan melihat peran pengaturan kerja fleksibel terhadap kegagalan kognitif. Penelitian ini akan melihat bagaimana penerapan FWA secara menyeluruh (fleksibilitas waktu dan tempat) dapat meningkatkan persepsi kontrol individu terkait tanggung jawab pekerjaan dan rumah tangga, sehingga dapat berperan dalam penurunan tingkat kegagalan kognitif pada karyawan, khususnya dalam situasi pandemi COVID-19. Berangkat dari penjelasan tersebut, maka terdapat dua hipotesis yang diajukan dalam penelitian ini yaitu, H1: Persepsi kontrol di tempat kerja berperan sebagai mediator dalam hubungan antara pengaturan kerja fleksibel dengan (a) kegagalan kognitif di tempat kerja dan (b) kegagalan kognitif di rumah. H2: Persepsi kontrol di rumah berperan sebagai mediator dalam hubungan antara pengaturan kerja fleksibel dengan (a) kegagalan kognitif di tempat kerja dan (b) kegagalan kognitif di rumah. 


\section{Metode}

Responden penelitian ini adalah individu yang berprofesi sebagai karyawan di perusahaan di Indonesia, yang sedang menerapkan pengaturan kerja fleksibel, serta telah bekerja minimal 6 bulan. Teknik pengambilan sampel pada penelitian ini adalah dengan non-probability sampling. Alasan pemilihan teknik ini adalah karena jumlah pasti dari populasi tidak diketahui, sehingga pengambilan sampel dilakukan berdasarkan kemudahan akses dalam menjangkau responden (Gravetter \& Forzano, 2012). Jumlah responden yang memenuhi kriteria sebanyak 260 orang. Dari 260 data tersebut dilakukan pembersihan data yang merupakan pencilan, sehingga diperoleh sebanyak 225 data responden yang dapat diolah.

Penelitian kuantitatif ini menggunakan dengan desain non-eksperimental, dengan pengaturan kerja fleksibel (FWA) sebagai variabel bebas, persepsi kontrol di tempat kerja dan di rumah sebagai mediator, serta kegagalan kognitif di tempat kerja dan di rumah sebagai variabel terikat. Berikut ini adalah model dari penelitian ini.

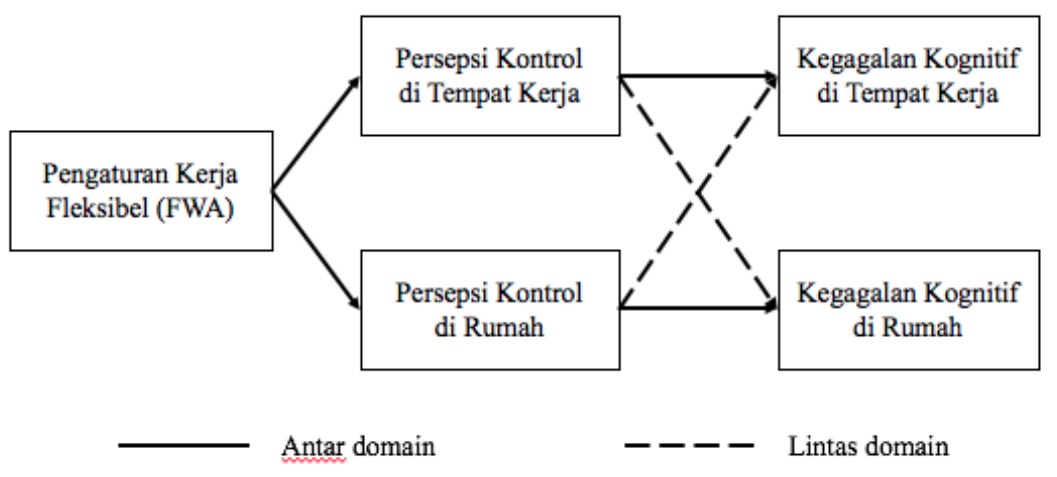

Gambar 1. Model penelitian

Terdapat beberapa alat ukur yang digunakan dalam penelitian ini. Pengukuran tingkat kegagalan kognitif dilakukan dengan menggunakan dua alat ukur berbeda berdasarkan setingnya, yaitu tempat kerja dan rumah. Alat ukur yang digunakan untuk mengukur tingkat kegagalan kognitif individu di tempat kerja adalah Workplace Cognitive Failure Scale (WCFS) yang dikembangkan oleh Wallace dan Chen (2005). Sedangkan untuk mengukur tingkat kegagakan kognitif individu di rumah, peneliti menggunakan Home Cognitive Failure Scale (HCFS) hasil modifikasi dari WCFS yang dilakukan oleh Hsu et al. (2019). Koefisien reliabilitas untuk WCFS adalah sebesar 0,89, sementara untuk HCFS adalah sebesar 0,91. Baik WCFS maupun HCFS, masing-masing memiliki 15 aitem yang menggunakan skala tipe Likert dari skala 1 untuk pilihan "Tidak Pernah" hingga skala 6 untuk pilihan "Selalu". Contoh aitem alat ukur WCFS adalah "Gagal mengingat suatu prosedur kerja", sementar untuk alat ukur HCFS contoh 
aitemnya adalah "Tidak memberikan perhatian penuh pada tanggung jawab rumah tangga"

Kedua, untuk mengukur sikap karyawan dalam penerapan pengaturan kerja fleksibel digunakan Flexible Work Options Questionnaire (FWOQ) yang dikembangkan oleh (Albion, 2004). Terdapat empat dimensi dalam FWOQ yaitu keseimbangan kehidupan dan pekerja (work life balance), hambatan terkait pandangan rekan kerja di kantor (barriers - others), hambatan terkait keuangan dan biaya (barriers - cost), serta hambatan terkait perasaan disosiasi dan komitmen dengan tempat kerja (barriers commitment). Terdapat 13 item dalam FWOQ dengan menggunakan skala tipe Likert dari skala 1 untuk pilihan "Sangat Tidak Setuju" hingga skala 6 untuk pilihan "Sangat Setuju". Contoh aitem untuk alat ukur FWOQ yaitu "Pengaturan kerja yang fleksibel membantu saya untuk menyeimbangkan pekerjaan dengan kehidupan pribadi saya". Koefisien reliabilitas untuk FWOQ pada penelitian ini adalah sebesar 0,82.

Ketiga, terkait persepsi kontrol individu, digunakan dua alat ukur yaitu Control at Work Scale (CWS) untuk mengukur persepsi kontrol di tempat kerja dan Control at Home Scale (CHS) untuk mengukur persepsi kontrol di rumah. Kedua alat ukur tersebut di kembangkan oleh Lapierre dan Allen (2012) dengan masing-masing alat ukur terdiri dari 6 aitem dengan skala tipe Likert dari skala 1 untuk pilihan "Tidak Ada Kontrol" hingga skala 6 untuk pilihan "Kontrol Penuh". Contoh aitem untuk alat ukur CWS adalah "Seberapa banyak keputusan yang dapat Anda buat terkait pekerjaan Anda?", sementara contoh aitem untuk alat ukur CHS adalah "Seberapa besar kendali Anda dalam menentukan cara untuk memenuhi tanggung jawab di dalam keluarga/rumah?". Koefisien reliabilitas untuk CWS adalah sebesar 0,82 dan 0,89 untuk CHS.

Metode analisis untuk menguji hipotesis dilakukan dengan metode analisis mediasi. Analisis dilakukan dengan menggunakan program Macro PROCESS yang dikembangkan oleh Hayes (2013) yang tersedia pada perangkat lunak SPSS versi 25. Model yang digunakan dalam pengujian hipotesis ini adalah Model 4, yang bertujuan untuk melihat pengaruh tidak langsung dari variabel bebas kepada variabel terikat melalui mediator (Hayes, 2013).

\section{Hasil}

Hasil yang didapatkan berdasarkan pengolahan data secara deskriptif memberikan gambaran umum terkait responden penelitian seperti yang disajikan pada Tabel 1 berikut ini. 
Tabel 1.

Gambaran Umum Partisipan Penelitian (N=225 orang)

\begin{tabular}{ccc}
\hline Aspek Demografis & $\mathbf{n}$ & $\mathbf{\%}$ \\
\hline Jenis Kelamin & 100 & \\
$-\quad$ Laki-laki & 125 & 44,4 \\
$-\quad$ Perempuan & & 55,6 \\
Usia & 135 & \\
$-\quad 20-34$ & 66 & 60 \\
$-\quad 35-49$ & 24 & 29,3 \\
$-\quad 50-64$ & & 10,7 \\
Masa Kerja & 87 & 38,7 \\
$-\quad<2$ tahun & 59 & 26,2 \\
$-\quad 2-10$ tahun & 79 & 35,1 \\
\hline
\end{tabular}

Dari Tabel 1 dapat dilihat bahwa jumlah responden laki-laki dan perempuan tidak jauh berbeda dengan perbandingan 4:5. Sedangkan dari segi usia, didominasi oleh responden dengan usia antara 20 hingga 34 tahun sebanyak 135 orang $(M=33,68$ tahun; $S D=10,45)$. Kemudian terkait masa kerja, didominasi oleh responden yang telah bekerja kurang dari dua tahun yaitu sebanyak 87 orang $(38,7 \%)$.

Setelah melakukan pembersihan data dan pencilan, serta menganalisis data demografis responden, maka selanjutnya dilakukan pengujian hipotesis. Untuk masingmasing hipotesis 1 ( $a$ dan $b$ ) serta 2 ( $a$ dan $b$ ), terbagi menjadi tiga bagian hubungan, yaitu (1) peran FWA terhadap persepsi kontrol (jalur a), (2) peran FWA dan persepsi kontrol terhadap kegagalan kognitif (jalur b dan c), dan (3) analisis model mediasi secara keseluruhan (jalur c').

Tabel 2.

Hasil Analisis Hubungan FWA dengan Persepsi Kontrol di Tempat Kerja dan di Rumah

\begin{tabular}{llllll}
\hline Persepsi Kontrol & $\mathbf{b}$ & $\mathbf{t}$ & $\mathbf{p}$ & $\mathbf{L L C I}$ & ULCI \\
\hline $\begin{array}{l}\text { Di Tempat Kerja } \\
\quad \text { Constant }\end{array}$ & 22,76 & 14,01 & $0,00^{* *}$ & 19,57 & 25,97 \\
$\quad$ FWA & 0,09 & 3,21 & $0,00^{* *}$ & 0,04 & 0,16 \\
$\begin{array}{l}\text { Di Rumah } \\
\quad\end{array}$ & & & & \\
$\quad$ Constant & 26,33 & 15,78 & $0,00^{* *}$ & 23,05 & 29,63 \\
$\quad$ FWA & 0,05 & 1,50 & 0,13 & $-0,01$ & 0,11 \\
\hline b, unstandardized regression estimate; CI (lower), confidence interval lower bound; CI (higher),
\end{tabular}


Hasil analisis pada jalur a yang tertera di Tabel 2, menunjukkan bahwa FWA secara signifikan dapat memprediksi persepsi kontrol di tempat kerja $(b=0,09, t=3,21, p<$ $0,01)$, dengan nilai $\mathrm{R}^{2}=0,045$. Artinya, $4,5 \%$ varians persepsi kontrol di tempat kerja dapat dijelaskan oleh FWA. Nilai $b$ yang bersifat positif menunjukkan bahwa peningkatan pada FWA akan diikuti dengan peningkatan persepsi kontrol di tempat kerja, dan sebaliknya. Akan tetapi FWA tidak signifikan dalam memprediksi persepsi kontrol di rumah $(b=$ $0,05, t=1,50, p>0,05)$.

Tabel 3.

Hasil Analisis Hubungan FWA dan Persepsi Kontrol di Tempat Kerja terhadap Kegagalan Kognitif di Tempat Kerja dan di Rumah

\begin{tabular}{llllll}
\hline Kegagalan Kognitif & $\mathbf{b}$ & $\mathbf{t}$ & $\mathbf{p}$ & $\mathbf{L L C I}$ & ULCI \\
\hline $\begin{array}{l}\text { Di Tempat Kerja } \\
\quad \text { Constant }\end{array}$ & 50,91 & 9,64 & $0,00^{* *}$ & 40,50 & 61,32 \\
FWA & $-0,18$ & $-2,42$ & $0,02^{*}$ & $-0,32$ & $-0,03$ \\
PCW & $-0,35$ & $-2,18$ & $0,03^{*}$ & $-0,66$ & $-0,03$ \\
Di Rumah & & & & & \\
$\quad$ Constant & 45,47 & 8,67 & $0,00^{* *}$ & 35,14 & 55,81 \\
FWA & $-0,15$ & $-2,09$ & $0,03^{*}$ & $-0,30$ & $-0,01$ \\
PCW & $-0,25$ & $-1,57$ & 0,11 & $-0,56$ & 0,06 \\
\hline
\end{tabular}

$b$, unstandardized regression estimate; CI (lower), confidence interval lower bound; CI (higher), confidence interval higher bound; FWA, flexible work arrangements; PCW, perceived control at work. ${ }^{*} p<0,05{ }^{* *} p<0,01$

Tabel 3 menjelaskan hubungan variabel bebas dan mediator dengan variabel terikat pada hipotesis 1. Berdasarkan hasil analisis tersebut, diketahui bahwa FWA secara signifikan memprediksi kegagalan kognitif di tempat kerja $(b=-0,18, t=-2,42, p<0,05)$ dengan persepsi kontrol di tempat kerja dilibatkan dalam model. Secara terpisah, persepsi kontrol di tempat kerja diketahui juga signifikan memprediksi kegagalan kognitif di tempat kerja $(b=-0,35, t=-2,18, p<0,05)$. Nilai $\mathrm{R}^{2}=0,057$ menunjukkan bahwa 5,7\% varians kegagalan kognitif di tempat kerja dapat dijelaskan oleh model tersebut. Hasil yang signifikan juga ditemukan dalam kemampuan FWA memprediksi kegagalan kognitif di rumah $(b=-0,15$, $t=-2,09, p<0,05)$. Akan tetapi, persepsi kontrol di tempat kerja tidak signifikan memprediksi kegagalan kognitif di rumah $(b=-0,25, t=-1,57, p>0,05)$. Kedua model hubungan di atas memiliki nilai $b$ negatif menandakan bahwa peningkatan FWA dan persepsi kontrol di tempat kerja akan diikuti dengan penurunan kegagalan kognitif baik di tempat kerja maupun di rumah. 
Tabel 4.

Hasil Analisis Hubungan FWA dan Persepsi Kontrol di Rumah terhadap Kegagalan Kognitif di Tempat Kerja dan di Rumah

\begin{tabular}{llllll}
\hline Kegagalan Kognitif & $\mathbf{b}$ & $\mathbf{t}$ & $\mathbf{p}$ & LLCI & ULCI \\
\hline Di Tempat Kerja & & & & & \\
$\quad$ Constant & 53,13 & 9,51 & $0,00^{* *}$ & 42,11 & 64,13 \\
FWA & $-0,20$ & $-2,70$ & $0,00^{* *}$ & $-0,33$ & $-0,05$ \\
PCH & $-0,38$ & $-2,49$ & $0,01^{*}$ & $-0,69$ & $-0,08$ \\
Di Rumah & & & & & \\
$\quad$ Constant & 50,21 & 9,11 & $0,00^{* *}$ & 39,35 & 61,07 \\
FWA & $-0,16$ & $-2,22$ & $0,02^{*}$ & $-0,29$ & $-0,01$ \\
PCH & $-0,39$ & $-2,58$ & $0,01^{*}$ & $-0,69$ & $-0,09$ \\
\hline
\end{tabular}

$b$, unstandardized regression estimate; $C I$ (lower), confidence interval lower bound; CI (higher), confidence interval higher bound; FWA, flexible work arrangements; $\mathrm{PCH}$, perceived control at home. ${ }^{*} p<0,05 * * p<0,01$

Pada Tabel 4, ditemukan bahwa FWA signifikan memprediksi kegagalan kognitif di tempat kerja ketika persepsi kontrol di rumah dilibatkan dalam model $(b=-0,20, t=-2,70$, $p<0,01)$. Persepsi kontrol di rumah juga signifikan memprediksi langsung kegagalan kognitif di tempat kerja $(b=-0,38, t=-2,49, p<0,05)$. Model ini memiliki nilai $R^{2}=0,063$ atau sebesar 6,3\% varians kegagalan kognitif di tempat kerja dapat dijelaskan oleh variabel FWA dan persepsi kontrol di rumah. Demikian juga pada model selanjutnya, FWA $(b=-0,16, t=-2,22, p<0,05)$ dan persepsi kontrol $(b=-0,39, t=-2,58, p<0,05)$ signifikan memprediksi kegagalan kognitif di rumah. Dengan nilai $\mathrm{R}^{2}=0,055$, atau 5,5\% varians kegagalan kognitif di rumah dapat dijelaskan oleh FWA dan juga persepsi kontrol di rumah. Model hubungan pada Tabel 4 menghasilkan nilai $b$ negatif yang menandakan terjadinya peningkatan FWA dan persepsi kontrol di rumah akan diikuti dengan penurunan kegagalan kognitif baik di tempat kerja dan di rumah.

Tabel 5.

Hasil Analisis Total Effect FWA terhadap Kegagalan Kognitif di Tempat Kerja dan di Rumah

\begin{tabular}{llllll}
\hline Kegagalan Kognitif & $\mathbf{b}$ & $\mathbf{t}$ & $\mathbf{p}$ & LLCI & ULCI \\
\hline $\begin{array}{l}\text { Di Tempat Kerja } \\
\quad\end{array}$ & & & & & \\
$\quad$ Constant & 43,02 & 11,07 & $0,00^{* *}$ & 35,37 & 50,67 \\
$\quad$ FWA & $-0,21$ & $-2,93$ & $0,00^{* *}$ & $-0,35$ & $-0,06$ \\
Di Rumah & & & & & \\
$\quad$ Constant & 39,84 & 10,38 & $0,00^{* *}$ & 32,28 & 47,40 \\
$\quad$ FWA & $-0,17$ & $-2,46$ & $0,01^{* *}$ & $-0,31$ & $-0,03$ \\
\hline
\end{tabular}


$b$, unstandardized regression estimate; CI (lower), confidence interval lower bound; CI (higher), confidence interval higher bound; FWA, flexible work arrangements. ${ }^{*} p<0,05{ }^{* *} p<0,01$

Tabel 5 menunjukkan total effect dari FWA terhadap kegagalan kognitif, ketika persepsi kontrol tidak diikutsertakan. Hasilnya, FWA signifikan memprediksi kegagalan kognitif baik di tempat kerja $(b=-0,21, t=-2,93, p<0,01)$ maupun di rumah $(b=-0,17, t=-2,46, p<$ $0,01)$. Dengan nilai $R^{2}=0,037$ untuk variabel kegagalan kognitif di tempat kerja, artinya $3,7 \%$ varians variabel tersebut dapat dijelaskan oleh FWA. Sementara untuk variabel kegagalan kognitif di rumah, memiliki nilai $\mathrm{R}^{2}=0,027$, artinya $2,7 \%$ varians variabel tersebut dapat dijelaskan dengan FWA. Hubungan langsung antara FWA dengan kegagalan kognitif memiliki nilai $b$ negatif, menandakan peningkatan FWA akan diikuti dengan penurunan tingkat kegagalan kognitif.

Tabel 6.

Hasil Analisis Indirect Effect antara FWA dengan Kegagalan Kognitif yang Dimediasi Oleh Persepsi Kontrol

\begin{tabular}{llllll}
\hline Persepsi Kontrol & $\begin{array}{l}\text { Kegagalan } \\
\text { Kognitif }\end{array}$ & Boot $\beta$ & SE & LLCI & ULCI \\
\hline Di tempat kerja & Di tempat kerja & $-0,03$ & 0,01 & $-0,07$ & $-0,01$ \\
& Di rumah & $-0,02$ & 0,01 & $-0,06$ & 0,01 \\
\hline Di rumah & Di tempat kerja & $-0,01$ & 0,01 & $-0,04$ & 0,01 \\
& Di rumah & $-0,01$ & 0,01 & $-0,05$ & 0,01 \\
\hline
\end{tabular}

$\beta$, standardized regression estimate; SE, standard error of unstandardized estimate; CI (lower), confidence interval lower bound; CI (higher), confidence interval higher bound.

Setelah mengetahui hasil analisis hubungan langsung dari FWA serta persepsi kontrol dengan kegagalan kognitif. Terakhir dilakukan analisis model mediasi keseluruhan dari masing-masing hipotesis (1a, 1b, 2a, dan 2b). Dari Tabel 6, diketahui bahwa terdapat pengaruh tidak langsung yang signifikan dari FWA terhadap kegagalan kognitif di tempat kerja yang dimediasi oleh persepsi kontrol di tempat kerja $(\beta=-0,003$, $S E=0,01,95 \%$ BCa CI [-0,07. -0,01]). Berdasarkan temuan tersebut maka dapat dikatakan bahwa hipotesis 1a diterima. Akan tetapi, tidak terdapat pengaruh tidak langsung yang signifikan dari FWA terhadap kegagalan kognitif di rumah yang dimediasi persepsi kontrol di tempat kerja, $(\beta=-0,02, S E=0,01,95 \% B C a C I[-0,06,0,01])$. Ditemukan juga bahwa tidak terdapat pengaruh tidak langsung yang signifikan antara FWA dengan kegagalan kognitif yang dimediasi oleh persepsi kontrol di rumah, baik di tempat kerja ( $\beta$ $=-0,01, S E=0,01,95 \% B C a C I[-0,04,0,01])$, maupun di rumah $(\beta=-0,01, S E=0,01,95 \%$ $B C a C I[-0,05,0,01])$. Dengan demikian, maka hipotesis $1 \mathrm{~b}, 2 \mathrm{a}$, dan $2 \mathrm{~b}$ ditolak. 


\section{Diskusi}

Hasil penelitian ini menunjukkan bahwa persepsi kontrol dapat berperan sebagai mediator dalam konteks tempat kerja. Dengan kata lain, karyawan yang menerapkan pengaturan kerja fleksibel yang tinggi dapat berdampak kepada peningkatan kontrol terkait urusan pekerjaan yang tinggi pula, yang kemudian akan berdampak pada penurunan kegagalan kognitif terkait urusan pekerjaan. Temuan ini sejalan dengan penelitian-penelitian terdahulu yang mengungkapkan bahwa dengan menerapkan pengaturan kerja fleksibel, karyawan dapat memiliki otonomi dalam mengatur perannya dalam urusan pekerjaan (Hsu et al., 2019; Thulin et al., 2019). Individu yang memiliki fleksibilitas dalam mengatur waktu dan lokasi kerjanya, secara tidak langsung memiliki kendali atas jadwal kerja dan pembagian waktu dalam pekerjaannya. Hal ini menunjukkan adanya kontrol yang baik pada individu dalam mengatur alur kerjanya. Dengan mengetahui pembagian waktu kerja yang sesuai, maka individu dapat lebih fokus dalam bekerja dan meminimalisasi terjadinya kesalahan dalam melakukan tugastugas terkait pekerjaannya.

Akan tetapi pada hipotesis $1 \mathrm{~b}, 2 \mathrm{a}$, dan $2 \mathrm{~b}$, tidak ditemukan peran mediator yang signifikan dalam hubungan antara pengaturan kerja fleksibel dengan kegagalan kognitif baik di tempat kerja maupun di rumah. Hasil penelitian menunjukkan bahwa pengaturan kerja fleksibel yang tinggi dapat meningkatkan kontrol individu terkait pekerjaan, namun tidak signifikan dalam menurunkan kegagalan kognitif terkait urusan rumah. Kemudian, pengaturan kerja fleksibel yang tinggi juga ditemukan tidak berpengaruh dalam meningkatkan kontrol individu terkait urusan rumah tangga, meskipun hasil analisis menunjukkan kontrol yang baik di rumah dapat menurunkan kegagalan kognitif terkait pekerjaan maupun rumah tangga. Hal ini dapat dijelaskan dengan temuan Lapierre dan Allen (2012), bahwa kegagalan dalam mengontrol tanggung jawab pekerjaan maupun rumah tangga akan berdampak kepada peningkatan kegagalan kognitif. Dari seluruh hasil tersebut, dapat dikatakan bahwa pengaturan kerja fleksibel lebih baik dalam meningkatkan kontrol individu terkait urusan pekerjaan, namun tidak pada kontrol terkait urusan rumah tangga. Temuan ini dikuatkan dengan penelitian yang menunjukkan bahwa penerapan pengaturan kerja fleksibel yang tinggi berkaitan erat dengan tingginya tingkat work-to-home conflict pada karyawan (Lott, 2017).

Ketiadaan kontrol yang tidak seimbang dalam urusan pekerjaan dan rumah tangga, dapat menyebabkan konflik terkait pekerjaan dan rumah tangga atau biasa disebut work-family conflict (WFC). Sejalan dengan penelitian yang dilakukan oleh Beigi, Shirmohammadi, dan Stewart (2018), bahwa individu yang menerapkan pengaturan kerja fleksibel justru memiliki tingkat WFC yang tinggi. Penelitian tersebut menemukan bahwa pengaturan kerja fleksibel dapat berperan dalam menurunkan WFC dalam kondisikondisi tertentu. Pertama, karyawan sudah mengetahui preferensi manajemen batasan 
yang ia miliki terkait tugas pekerjaan dan rumah tangga. Kedua, karyawan diberikan keleluasaan dan pengetahuan terkait manajemen waktu yang baik. Serta ketiga, tahapan karier dan keluarga yang dimiliki individu, dikatakan bahwa karyawan dalam tahap awal karier serta yang mengasuh anak kecil di rumah adalah yang paling merasakan keuntungan dari pengaturan kerja fleksibel dalam menurunkan WFC (Beigi et al., 2018).

Selain itu pada penelitian yang dilakukan oleh Lapierre dan Allen (2012) dijelaskan bahwa individu yang tidak dapat membedakan/mengontrol perannya dalam hal pekerjaan dan rumah tangga akan lebih mungkin mengalami konflik terkait keluarga dan pekerjaan. Hal ini berdampak kepada kesulitan secara psikologis untuk melepaskan diri dari pekerjaannya, sehingga lebih sulit untuk menghindari terjadinya kegagalan kognitif. Individu yang kesulitan mengontrol tugas-tugasnya, tidak hanya akan mengalami kegagalan kognitif ketika melaksanakan pengaturan kerja fleksibel saja, tetapi hal serupa juga akan dialami saat melaksanakan kerja dari kantor langsung.

Selain karena kurangnya kontrol yang baik dalam diri individu, dalam situasi pandemi COVID-19 saat ini kesulitan untuk beradaptasi dalam lingkungan kerja yang baru mungkin juga menjadi tantangan. Dalam situasi pandemi saat ini, penerapan pengaturan kerja fleksibel bukanlah sebuah pilihan namun tuntutan yang harus dipilih oleh perusahaan. Dengan penerapan yang bisa dikatakan mendadak dan tanpa persiapan yang matang, banyak perusahaan tidak memberikan pengetahuan terkait manajemen waktu yang ideal ketika karyawan diharuskan untuk bekerja dari rumah. Tidak adanya regulasi yang jelas terkait bekerja dari rumah, dapat menyebabkan jam kerja yang terlampau fleksibel hingga melebihi jam kerja yang sesungguhnya. Selain itu, beban kerja yang bisa melebihi jumlah normal ketika bekerja di kantor. Karyawan tentu membutuhkan waktu untuk beradaptasi dalam menangani tugas-tugas pekerjaan tersebut, sekaligus dapat melaksanakan tugas rumah tangga di waktu yang hampir bersamaan. Lapierre dan Allen (2012) menambahkan bahwa dalam upaya menurunkan kegagalan kognitif ketika menerapkan pengaturan kerja fleksibel, karyawan harus menyempatkan diri untuk melakukan "pemulihan". Artinya, karyawan harus bisa meluangkan waktu untuk memisahkan diri secara psikologis dari pekerjaan, misalnya dengan tidak memikirkan dan berurusan dengan pekerjaan ketika memiliki waktu luang di hari libur atau akhir pekan. Hal ini tentu harus dibarengi dengan dukungan dari perusahaan dalam menghormati hak karyawan.

Dalam penelitian ini, terdapat beberapa keterbatasan. Pertama, terkait jumlah responden yang masih belum cukup mewakili karyawan di perusahaan yang saat ini menerapkan pengaturan kerja fleksibel. Oleh karena itu, penelitian selanjutnya dapat menambah jumlah responden sehingga memungkinkan untuk dilakukan generalisasi. Kedua, pada penelitian ini masih belum dibedakan terkait jenis dari pengaturan kerja fleksibel, apakah responden hanya menerapkan fleksibilitas waktu atau juga fleksibilitas lokasi. Hal ini dapat memberikan hasil yang berbeda terhadap kontrol yang dimiliki individu dan perannya terhadap tingkat kegagalan kognitifnya. Ketiga, peneliti belum 
mengidentifikasi alasan dari pelaksanaan pengaturan kerja fleksibel yang dilakukan responden. Hal ini berkaitan dengan bagaimana individu memersepsi dan memiliki persiapan terkait pengaturan kerja fleksibel. Karyawan yang perusahaannya sudah terbiasa menerapkan pengaturan kerja fleksibel mungkin sudah lebih siap dan memiliki manajemen waktu yang baik dibandingkan karyawan yang perusahaannya baru menerapkan pengaturan kerja fleksibel akibat tuntutan situasi pandemi COVID-19. Terakhir, penelitian ini belum mengidentifikasi bidang pekerjaan responden, sehingga tidak dapat diketahui apakah beban kerja yang dimiliki responden setara atau berbeda yang mungkin berdampak kepada cara kerja dan manajemen waktu yang diterapkan.

\section{Kesimpulan}

Berdasarkan hasil penelitian dan diskusi yang telah disampaikan di atas, maka dapat disimpulkan bahwa pengaturan kerja fleksibel yang tinggi dapat meningkatkan persepsi kontrol individu terkait pekerjaannya, yang kemudian berdampak kepada penurunan kegagalan kognitif terkait pekerjaan, tetapi tidak kepada penurunan kegagalan kognitif terkait tugas rumah tangga. Selain itu, pengaturan kerja fleksibel tidak dapat meningkatkan persepsi kontrol individu terkait tugas rumah tangga yang dapat berdampak kepada penurunan kegagalan kognitif di tempat kerja maupun rumah. Untuk dapat meningkatkan persepsi kontrol tersebut, perusahaan dapat memberikan pengetahuan atau informasi terkait manajemen waktu yang baik dalam menjalankan tugas pekerjaan dan rumah selama melaksanakan pengaturan kerja fleksibel. Dengan demikian diharapkan kegagalan kognitif individu juga dapat menurun.

\section{Saran}

Terdapat beberapa saran untuk penelitian selanjutnya, antara lain terkait responden penelitian. Sebaiknya dapat diidentifikasi apakah responden sudah pernah menerapkan pengaturan kerja fleksibel sebelumnya atau baru saja menerapkannya karena adanya fenomena COVID-19 ini. Dengan demikian dapat diketahui apakah karyawan yang sudah terbiasa dengan pengaturan kerja fleksibel memperoleh pengetahuan terkait manajemen waktu sebagai bentuk dukungan dari perusahaan. Sementara untuk karyawan yang masih dalam proses adaptasi bekerja di rumah akibat pandemi, bisa digali persiapan apa yang dilakukan karyawan dan perusahaan dalam mengantisipasi dampak negatif dari pengaturan kerja fleksibel tersebut. Kemudian, penting juga untuk mengidentifikasi jenis pengaturan kerja fleksibel yang dilakukan karyawan, apakah sebatas fleksibilitas waktu, fleksibilitas lokasi, atau gabungan keduanya. Selain itu, peneliti juga dapat mengidentifikasi bidang pekerjaan responden, karena memungkinkan adanya perbedaan beban kerja dan tanggung jawab terkait pekerjaannya. Terakhir, terdapat saran praktis untuk penelitian ini yaitu terkait tahapan karier dan keluarga. Peneliti dapat mengidentifikasi apakah responden berada dalam tahap awal, tengah, atau 
akhir dalam kariernya. Serta bagaimana kondisi keluarga responden saat ini, memiliki berapa tanggungan dan jika memiliki anak, sedang dalam kondisi seperti apa (misal balita, sekolah, atau sudah kuliah/bekerja). Hal ini dapat membagi responden ke dalam kelompok yang berbeda sesuai dengan tanggung jawab yang dimiliki responden di samping tanggung jawab terkait pekerjaan.

\section{Kepustakaan}

Albion, M. J. (2004). A Measure of attitudes towards flexible work options. Australian Journal of Management, 29(2), 275-294. https://doi.org/10.1177/031289620402900207

Allen, T. D., Golden, T. D., \& Shockley, K. M. (2015). How effective is telecommuting? Assessing the status of our scientific findings. Psychological Science in the Public Interest, 16(2), 40-68. https://doi.org/10.1177/1529100615593273

Allen, T. D., Johnson, R. C., Kiburz, K. M., \& Shockley, K. M. (2013). Work-family conflict and flexible work arrangements: Deconstructing flexibility. Personnel Psychology, 66(2), 345-376. https://doi.org/10.1111/peps.12012

Beigi, M., Shirmohammadi, M., \& Stewart, J. (2018). Flexible work arrangements and work-family conflict: A metasynthesis of qualitative studies among academics. Human Resource Development Review, 17(3), 314-336. https://doi.org/10.1177/1534484318787628

Binnewies, C., Sonnentag, S., \& Mojza, E. J. (2009). Daily performance at work: Feeling recovered in the morning as a predictor of day-level job performance. Journal of Organizational Behavior, 30(1), 67-93. https://doi.org/10.1002/job.541

Bloom, N., Liang, J., Roberts, J., \& Ying, Z. J. (2015). Does working from home work? Evidence from a chinese experiment. Quarterly Journal of Economics. https://doi.org/10.1093/qje/qju032

Broadbent, D. E., Cooper, P. F., FitzGerald, P., \& Parkes, K. R. (1982). The cognitive failures questionnaire (CFQ) and its correlates. British Journal of Clinical Psychology, 21(1), 1-16. https://doi.org/10.1111/j.2044-8260.1982.tb01421.x

Chen, Y., \& Fulmer, I. S. (2018). Fine-tuning what we know about employees' experience with flexible work arrangements and their job attitudes. Human Resource Management, 57(1), 381-395. https://doi.org/10.1002/hrm.21849

Elfering, A., Grebner, S., \& Boillat, C. (2013). Busy at work and absent-minded at home: Mentalworkload, cognitive failure, and domestic falls. Swiss Journal of Psychology, 72(4), 219-228. https://doi.org/10.1024/1421-0185/a000114

Elfering, A., Grebner, S., \& de Tribolet-Hardy, F. (2013). The long arm of time pressure at work: Cognitive failure and commuting near-accidents. European Journal of Work and $\begin{array}{lll}\text { Organizational } & \text { Psychology, }\end{array}$ https://doi.org/10.1080/1359432X.2012.704155

Elfering, A., Grebner, S., \& Ebener, C. (2015). Workflow interruptions, cognitive failure 
and near-accidents in health care. Psychology, Health and Medicine, 20(2), 139-147. https://doi.org/10.1080/13548506.2014.913796

Elfering, A., Grebner, S., \& Haller, M. (2012). Railway-controller-perceived mental work load, cognitive failure and risky commuting. Ergonomics, 55(12), 1463-1475. https://doi.org/10.1080/00140139.2012.718802

Elsayed, M., Ghazi, G., \& Abdelaal, H. (2019). Cognitive Failure , Perceived Stress and Self-Efficacy among Graduate Nursing Cognitive Failure, Perceived Stress and SelfEfficacy among Graduate Nursing Students. Alexandria University , Egypt, (June), 113.

Fachriansyah, R. (2020, 8 April). Coronavirus means working from home for many. But some say it's easier said than done. The Jakarta Post. Diakses dari https://www.thejakartapost.com/news/2020/04/08/coronavirus-means-working-fromhome-for-many-but-some-say-its-easier-said-than-done.html.

Gravetter, F. J., \& Forzano, L.-A. B. (2012). Research methods for the behavioral sciences, 4th edition. Wadsworth, Cengage Learning.

Hakim, R. N., Farisa, F. C., \& Kamil, I. (2020, 9 September). UPDATE: Bertambah 3.989, Kasus Covid-19 di Indonesia Capai 244.676. Kompas.com. Diakses dari https://nasional.kompas.com/read/2020/09/20/15255191/update-bertambah-3989kasus-covid-19-di-indonesia-capai-244676? page=all.

Hayes, A. F. (2013). Introduction to mediation: A regression-based approach. Guilford Press.

Hobfoll, S. E. (2002). Social and psychological resources and adaptation. Review of General Psychology, 6(4), 307-324. https://doi.org/10.1037/1089-2680.6.4.307

Hsu, Y. S., Chen, Y. P., \& Shaffer, M. A. (2019). Reducing work and home cognitive failures: The roles of workplace flextime use and perceived control. Journal of Business and Psychology, 36(1), 155-172. https://doi.org/10.1007/s10869-019-09673-4

Ihsanuddin. (2020, 3 Maret). Fakta lengkap kasus pertama virus corona di Indonesia. Kompas.com. Diakses dari https://nasional.kompas.com/read/2020/03/03/06314981/fakta-lengkap-kasuspertama-virus-corona-di-indonesia?page=all

International Workplace Group. (2019). THE IWG GLOBAL WORKSPACE SURVEY Welcome to Generation Flex - the employee power shift [Data set]. International Workplace Group. Diakses dari https://www.iwgplc.com/global-workspace-survey2019

Kelliher, C., \& Anderson, D. (2010). Doing more with less? flexible working practices and the intensification of work. Human Relations, 63(1), 83-106. https://doi.org/10.1177/0018726709349199

Kelly, E. L., \& Moen, P. (2007). Rethinking the clockwork of work: Why schedule control may pay off at work and at home. Advances in Developing Human Resources, 9(4), 487506. https://doi.org/10.1177/1523422307305489

Lapierre, L. M., \& Allen, T. D. (2012). Control at work, control at home, and planning 
behavior: Implications for work-family conflict. Journal of Management, 38(5), 15001516. https://doi.org/10.1177/0149206310385868

Lott, Y. (2017). Stressed despite or because of flexible work arrangements Flexible work arrangements, job pressure and work-to-home conflict for women and men in Germany, (August 2017), 36. Retrieved from https://www.boeckler.de/106575_110305.htm

Manoochehri, G., \& Pinkerton, T. (2003). Managing telecommuters: Opportunities and challenges. American Business Review.

Maruyama, T., \& Tietze, S. (2012). From anxiety to assurance: Concerns and outcomes of telework. Personnel Review, 41(4), 450-469. https://doi.org/10.1108/00483481211229375

Rocha, C. T. M. da, \& Amador, F. S. (2018). Telework: conceptualization and issues for analysis O teletrabalho: conceituação e questões para análise Resumo, 16(1), 152-162.

Thomas, L. T., \& Ganster, D. C. (1995). Impact of family-supportive work variables on work-family conflict and strain: A control perspective. Journal of Applied Psychology, 80(1), 6-15. https://doi.org/10.1037/0021-9010.80.1.6

Thulin, E., Vilhelmson, B., \& Johansson, M. (2019). New telework, time pressure, and time use control in everyday life. Sustainability (Switzerland), 11(11). https://doi.org/10.3390/su11113067

Velarosdela, R. N. (2020, 14 September). PSBB Jakarta dimulai hari ini, simak 17 aturan baru yang wajib dipatuhi warga. Kompas.com. Diakses dari https://megapolitan.kompas.com/read/2020/09/14/06462751/psbb-jakarta-dimulaihari-ini-simak-17-aturan-baru-yang-wajib-dipatuhi?page=all.

Wallace, J. C., \& Chen, G. (2005). Development and validation of a work-specific measure of cognitive failure: Implications for occupational safety. Journal of Occupational and Organizational Psychology, 78(4), 615-632.https:/doi.org/10.1348/096317905X37442

Wattree, I. T. (2020). Family and flexibility: How flexible work arrangements influence organizational commitment and burnout. Doctoral Dissertation. Emporia State University. 